\title{
Labour Migration as a Livelihood Strategy in Far East Bhutan: a Case Study of a Marginal Bhutanese Community
}

\author{
Raghubir Chand
}

\begin{abstract}
The phenomenon of labour migration in Bhutan is triggered by the disparities in regional patterns in resource use under different sets of social and ecological conditions. The incidence of high poverty at large as well as climatic adversities of the place force people to move to more favourable places and nearby town areas to earn a livelihood on a temporary basis during certain periods of the year, particularly in the winter months. The focus of the present paper is on migrant workers and their families engaged on purely remunerative activities. These migrant workers are temporary workers and the most general reason for their movement is poverty. The relief of domestic unemployment pressure and earning of cash income serve two main objectives. With increasing demand for labour and awareness in the local market in recent years, labour has become a source of local economy and a safety valve for domestic unemployment. There has been no serious attempt as yet to study this aspect of labour migration in Bhutan. The present paper aims at investigating the current situation of labour migration in Bhutan on the basis of primary data collected in the year 2009 from the remotest village of Lauri located in eastern most corner of Bhutan.
\end{abstract}

Key words: livelihood strategy, labour migration system, Bhutan

\section{Migracija radne snage kao strategija privređivanja u istočnom Butanu: studija slučaja marginalnoga butanskog naselja}

Fenomen migracije radne snage u Butanu potaknut je regionalnim disparitetima u upotrebi resursâ u različitim ekološkim i društvenim okolnostima. Natprosječna razina siromaštva i nepovoljni klimatski čimbenici prisiljavaju ljude na migracije u područja s boljim mogućnostima privređivanja, najčešće privremeno tijekom zimskih mjeseci. Ovaj se rad bavi migracijom radnika i njihovih obitelji. Slabljenje pritiska nezaposlenosti na domaćem tržištu te priljev novčanih sredstava imaju dvije svrhe - porastom potrebe za radnom snagom na drugim tržištima posljednjih godina, rad je postao resurs lokalne ekonomije i sigurnosni ventil za probleme nezaposlenosti na domaćem tržištu. Malo je radova koji su se bavili problemom migracije radne snage u Butanu. Cilj je ovog rada analizirati trenutačnu situaciju migracije radne snage u Butanu na temelju istraživanja provedenog 2009. u naselju Lauri na krajnjem istoku Butana.

Ključne riječi: strategija privređivanja, migracija radne snage, Butan 


\section{INTRODUCTION}

Labour Migration presents both challenges and opportunities in today's globalized world. It has a crucial role in poverty reduction strategies and impinges upon diverse sections of the people in many ways. At individual and household level, it provides a major livelihood strategy for many people who may not have found such an outlet domestically (Khatri, 2007, 4). At the international level, the globalization process has facilitated movements of capital, goods, services and information in a significant way, and the movement of labour, a factor over which many developing countries of the South enjoy a comparative advantage. There has also been a growing appreciation of the economic, social and cultural impacts of international labour migration. While labour migration has increasingly become a livelihood option for many, there has also been increased recognition that appropriate policy measures should be in place to reduce the negative consequences and increase the gains from migration (Abrar, 2005).

Labour migration is a common phenomenon both within developing countries and between them and the developed countries. Most of the existing literature assumes that migration is a rational response to a given range of resources and choices. The high level of labour migration has led to a modification in the structure of family life and has transformed the social and economic position of the family. The new economics of labour migration argues that migration may set in motion a developmental dynamics, lessening production and investment constraints faced by households in imperfect market environments and creating income growth linkages (Taylor 1999, 63). Brown holds the view that labour migration discourages local development by producing a kind of 'low-level equilibrium trap' in which migrants and their families are only maintained at or near subsistence level by the low wages received. Due to lack of capital, productivity of the rural areas remains unchanged or declines, thus spawning further dependence on the migrant labour system. There is, however, a great complexity of links between migration and development. An important advance has been the growing understanding of the role of the social network and cultural capitals in the migratory process (Castles, 1999, 5). In 'dual economy' type models, the labourers move from the low-paid agriculture (rural/traditional) sector to a higher paid industrial (modern/ urban) one. A neo-Malthusian variant of the push factor is mainly held responsible for labour migration (Mosse et.el., 2002, 59).

Despite the differences of opinion and existences of many forms of labour migration, it seems sensible to begin with a micro-level survey of labour migration in Bhutan. This study of labour migration is based on a sample of 100 households in the village of Lauri to gain local insight from a far-eastern corner of Bhutan. All varieties of labour migrant employment taking place in winter as a form of temporary wage labour are surveyed with the job locations and type of work. In the present study, it is assumed that as long as the larger portion of human needs is met within the local ecosystem, the indigenous local economy survives with least human mobility. The labour force of the community moves out from the region in search of basic necessities when the ecological diversity is modified, reduced and displaced (Chand, 2009 a, 121). The topography and harsh climate restricts the cultivation of crops, as level land is scare and environmental constraints are severe. The cultivation of maize, foxtail millet, buckwheat and wheat is hardly enough to meet the annual requirement of the households. The agriculture fields are left fallow during 
the winter months, as such maximum households move out to work in lower valleys for their survival as part of traditionally built relationships with the people of neighbouring valley areas. The outflow of village folk with their animals and in relation to socio-cultural practices and religious performances also form an important part of the winter labour migration. The present work is therefore intended to address the issues of migration and the associated economy of a marginal Bhutanese society, isolated from the main stream of development. The impact of the ongoing process of globalization and the entry of market forces into these peripheral societies can be very well analyzed with the results obtained through this case study.

\section{OBJECTIVES}

The following are the main objectives of the study:

1. To explore the pattern of winter labour migration as an important aspect of Bhutanese rural livelihoods.

2. To look at the size, characteristics and composition of the labour migrants.

3. To study the rural-rural and rural-urban divide of the migrants.

4. To study the gender participation level of the migrants; and,

5. Finally, to discover the destination areas and regional distribution of labour migrants of the village of Lauri within Bhutan.

\section{MIGRATORY PRACTICES IN BHUTAN}

Bhutan is largely a migrant receiving country with approximately 18,000 foreign workers as reported in 2007 (Labour Market Information Bulletin, 2007 ). The present strength of legal labour migrant inflow is approximately 37,000 , the majority of whom being from India (Norbu,2008). The boom in hydropower generation, private construction and other such activities has increased the inflow of expatriate workers from India. Bhutan is heavily dependent on India for workers. The Ministry of Labour and Human Resources, Royal Government of Bhutan, recently reported that Bhutan is currently hiring 55,551 Indian workers resulting in a huge increase in payments made to them. That amounted to $\mathrm{Nu} 2.2$ billion in the 2010-2011 financial year, which is an increase of 75 percent from the previous year. Today, Bhutan has 2000 construction companies carrying over 7000 licenses for four work categories, namely building, traditional painting, roads and bridges and power \& telecommunication (Chhetri, 2012).

Outward migration from Bhutan is minimal, and limited data is available on documented migrants. Bhutanese leaving the country in search of work abroad are undocumented, but the number is very small. The phenomenon of international migration is not, therefore, a particularly relevant issue for Bhutan. The geography of Bhutan in the sense of difficult topography and severe climatic conditions, its policy of self-imposed isolation till the mid-1970's, and its own social, ethnic, administrative and institutional attributes of localities and regions have contributed towards a highly variable developmental process. Bhutanese, in general, are perceived as a relatively immobile peasant society. The low level of education, income and a lack of contact with the outside world are formidable 
barriers to their personal mobility. The patterns of work, thought and their movement are rigidly circumscribed in such cases; population circulation is often restricted to movements concerned with the tilling of land, pasturing animals, trips to fetch fuel wood and visits to local markets, relatives and to religious observances. The important types of movements in primitive societies such as Brokpas, the yak herders of eastern Bhutan and Layaps, the yak herders of the Laya region of western Bhutan, are mainly marked by their seasonal rhythm and migration to traditionally fixed pastures (Chand,2004). Another type of movement takes place from Bumthang, Ha and other high altitude valleys to Kurichu, Mangdue and other warmer valleys. Some other societies in the remotest parts of Bhutan used to barter their local produce with neighboring villages, symbolizing medieval economic conditions (Chand, 2009 b). Bhutanese were also in trade links with Tibet in the north and Assam and West Bengal in the south. The interaction between Bhutanese and Indians was very deep. They used to visit the Indian plains to buy salt and other items and also used to take a journey to Tibet for the same purpose. Within Bhutan, the fabrics woven by the women of the Kheng (a tribe living in south-central Bhutan), bamboo products and milk products etc. were important trading items, which were used to barter from one valley to another and from higher reaches to lower warmer valleys. There has also been a marked shift or displacement of Bhutanese people from less preferred localities to other safer locations, largely due to a high incidence of poverty and heavy taxation by feudal lords. Another important form of mobility is pilgrimage and retreat, because of its religious and social significance. These movements are not regular and do not follow a particular order. Pilgrimage is a lifetime ambition of a Buddhist family depending on its economic well-being and other prevailing circumstances. Visits to Lakhang (Buddhist temple) and tschechu (a local fair) from one region to another are a regular annual feature.

Bhutan embarked on the modern development path with road building and hydroelectricity projects initiated with financial support from India in 1961. Bhutan's extensive forests, mineral resources, and swift-running rivers offered great potential for future development, although preservation of the country's environment continued to rank high among the government's priorities. A series of five-year plans initiated in 1961 and financed primarily by India, have begun to improve transportation, modernize agriculture, and develop hydroelectric power. Indian workers holding work permits were employed to run these projects in the beginning. The Bhutanese workforce is now gradually being absorbed, due to the high demand for labour in the rapidly growing economy. There is a gradual reduction and replacement of foreign workers by nationals due to accelerated economic development and the construction boom. As of 2002, Bhutan had a government-set minimum wage of approximately $\$ 2.50$ per day, which provided a standard of living for a family. The workday was set at eight hours per day, with one hour for lunch. In addition, regular leisure days are required and overtime work is paid at a time-and-a-half rate. Although there is no minimum age for employment, the age of 18 was established "in all matters of the state." However, minors under the age of 18 frequently work in agriculture; perform chores on family farms and in shops during holidays and after school.

The Population and Housing Census of Bhutan in 2005 reported a national labour force of 256.895 individuals of the total persons aged 15 and above as economically active among the total population of 634.982 (Population and Housing Census of Bhutan, 2005). 
Thus the crude activity rate was 40.5 percent. The labour participation rates were higher for males $(71.7 \%)$ than for females (47.7\%). The majority of females are employed in the agriculture sector in Bhutan and most of unpaid workers are females $(58.2 \%)$. The activity rates of the population vary according to different levels of education and also vary across the age groups (Deki, 2009). Many who are classified as "employed" do not necessarily have a year-round job, but work seasonally, with little or no remuneration.

One significant movement of population in Bhutan is rural out-migration to a growing number of urban places in Bhutan. There is large and steady influx of rural people settling in urban areas. There are 61 urban centres in Bhutan in which 30 percent of its total population lived in 2005. The Resettlement Policy of the Royal Government of Bhutan in the southern districts has also led large scale relocation of Bhutanese population from north to south. However, despite rapid economic growth and the significant development efforts of the Royal Government of Bhutan, about 36 percent of the population was under the poverty level in 2003 (Poverty Analysis Report Bhutan, 2003), which has fallen to 23 percent in 2007 (Labour Market Information Bulletin, 2007). Accordingly, the country's Tenth Five Year Plan (2008-2013) target is to reduce poverty to 15 percent by June 2013 (Gross National Happiness Commission,2008). The severity of poverty is higher in rural areas compared to urban ones. The poverty rate measured as a head count ratio (HCR) was 30.9 percent in rural areas as against only 1.7 percent in urban areas (Labour Market Information Bulletin,2007). Furthermore, the poor usually come from isolated areas with inherent inequality and unavailability of resources throughout the year. The phenomenon of labour migration is triggered by such incidence of poverty at large, as well as by the climatic adversities of the place, which force people to move to nearby town areas to earn a livelihood on a temporary basis during certain periods, particularly in the winter months. However, their movement is restricted within the country due to security issues and also due to restrictions imposed by the Royal Government of Bhutan. However, Labour Migration to Assam and Arunachal Pradesh from far eastern parts of Bhutan has been a very important part of livelihood strategy for people living in these marginal border areas. From the linguistic and ethnic viewpoint, the far eastern corner of Bhutan is remarkably homogeneous with neighbouring Arunachal and Assam areas. The focus of the present paper is on migrant workers and their families engaged in purely remunerative activities. These migrant workers are temporary workers and the most general reason of their movement is poverty. The relief of domestic unemployment pressure and earning of cash income serve two main objectives. With increasing demand for labour and awareness in the local market, labour has become a source of the local economy and a safety valve for domestic unemployment. As yet, there has been no serious attempt to study this aspect of labour movement in Bhutan and the present paper aims at investigating the current situation of labour migration in Bhutan on the basis of primary data collected in the year 2009 from the remotest village of Lauri in the eastern most corner of Bhutan.

\section{GENERAL PROFILE OF THE VILLAGE OF LAURI}

The above description has provided an overview of selected migratory practices of the Bhutanese population on a very general scale. The discussion now turns to a micro-level case study of the village of Lauri. Lauri is the central village of the Lauri gewog (development 
block), which is located in the Dhansiri River Province of Far-East Bhutan. This is the most remotely located region of Bhutan. Administratively, the Lauri gewog falls under the Jomotshangkha dunkhag (sub-district) of Samdrup Jongkhar dzongkhag (district). Its eastern boundary is shared by Arunachal Pradesh of India and the Assam State of India lies in the south. The western boundary is shared by the Trashigang dongkhag (sub-district) of Bhutan. At least four to five days are needed to reach Lauri village on foot from Diafam town, which is connected by road through the Assam side. Diafam is a border town, now renamed as Jomotshangkha. The people of Lauri had originated from different parts of Bhutan. It is believed that people took refuge in Lauri village from Trashigang and some other parts of Bhutan during the reign of the Third King of Bhutan, to escape from the serfdom practice and also due to their inability to pay land taxes. At the same time, the people of the neighboring state of Arunachal Pradesh also settled here in the due course of time. The inhabitants of Lauri village are commonly known as "Lauriaps" meaning the people of Lauri, following the tradition of common village identities in Bhutan. Before the construction of a proper mule track, it was a journey of two weeks to reach Jomotshangkha and nearby Bharakhundu in India to buy salt and other items. The Lauriaps also used to take a journey to Tibet for the similar purpose. Lauri village was connected by wireless in 1980 and now it has a public telephone booth as well. A farm road is also under construction to link Lauri with the town of Jomotshangkha. Resin and kerosene is still used as the source of light in the village and fire wood is the main cooking fuel. A primary school and a basic health unit are located at the distance of one hour from the village, while the lower secondary school is at two days walking distance from the village. There are many places like Lauri in Bhutan (Fig. 1), living under such remote conditions.

The Lauri gewog has 13 villages with an area of $278 \mathrm{sq} . \mathrm{km}$ and a population of 2803 persons living in 697 households (Population and Housing Census of Bhutan, 2005). The main village is Lauri with 115 households spreading over a wide range of 1200 to 3500 metres above sea level. Shifting cultivation known as "tsheri" in eastern Bhutan and livestock rearing with production of cane and bamboo items are the traditional livelihood strategies in the village.

Due to the ban imposed on shifting cultivation, the shift from tsheri towards wet land and dry land cultivation is now taking place. The main crops grown in the village are maize, foxtail millet, buckwheat and wheat. Paddy cultivation is confined to a small scale. Vegetables like potato, radish, cabbage and chillies are produced in the village. Similarly to other indigenous groups in Bhutan, the capacities and means of living of Lauri's people are based on the natural resources around them. They are involved in the collection of chirata, a medicinal herb, which is the main source of cash income. Besides, the sale of local handicrafts to other Bhutanese also fetch them a good income. Lauriaps maintain their relation with the highlander community of Brokpas, who barter milk products with them. They are now earning a good part of their income as wage labour, transporting commodities to and from the town of Jomotshangkha.

The present sample, which covers 100 households, has a total of 607 persons with 300 males and 307 females. Household size is directly related to the stage of socio-economic transformation. Joint and large families are found mostly in the indigenous societies with a tendency of collectivism and co-operative living. The average size of households in the 


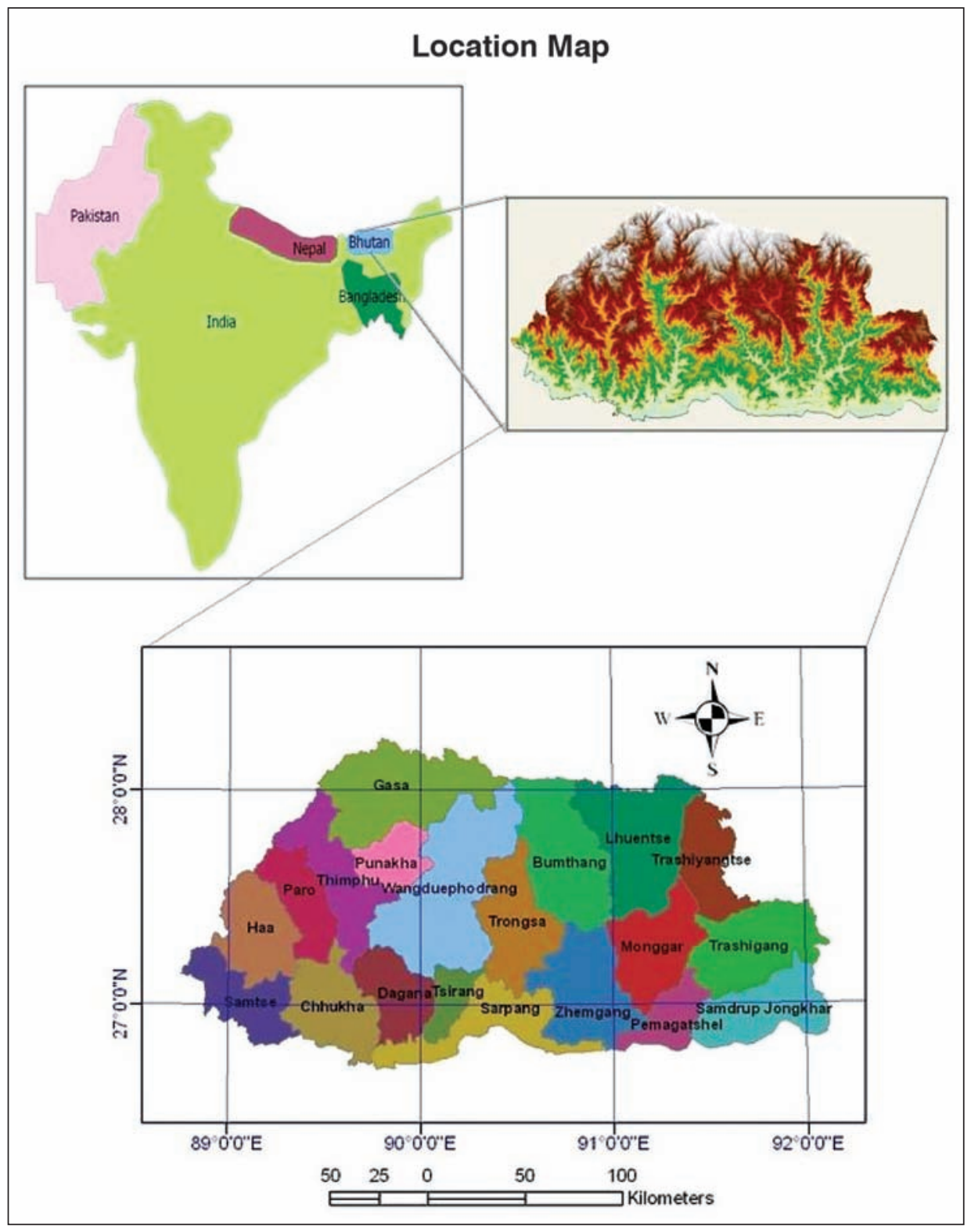

Fig.1 Location Map of Bhutan

Sl. 1. Karta Butana

Source: Population and Housing Census of Bhutan, 2005

Izvor: Popis stanovništva i kućanstava Butana, 2005. 
present sample is 6.07, ranging from below 2 to above 10 members per family. There are only 2 households with 2 members and only 1 with 11 members in the sample. About half of the sample households (47) have a family of 4 to 6 members followed by exactly one fourth of households (25) with 6 to 8 members. There are 16 households below 2 to 4 members and 11 households between 8 to 10 members. The educational attainment of the Lauriaps is gradually improving over the years with a literacy rate of 45.46 percent. The illiterate population is 52.00 percent. Those below the age of 6 years (20 children, i.e., 3.29\%) are not included under any category.

In the past, monastic education was being offered by the Lamas and 43 children ( $7.08 \%)$ are still receiving monastic education in the village. There are 17 persons $(2.80 \%)$ who have passed community school with a maximum number of 104 persons $(17.13 \%)$ with primary school. Those with lower secondary, middle and higher secondary education stand at 8.10 percent, 4.70 percent and 4.12 percent in the total population. One student, who has collected information for this study, is attending the undergraduate course at Sherubtse College Kanglung. There are 8 boys from the village attending the higher secondary school at the time of survey.

\section{LIVELIHOOD STATUS OF THE LAURIAPS}

Agriculture forms the basis of the village economy of the Lauriaps (the people of Lauri). The total working population in the village is recorded at 379 persons, which is 62.43 percent of the total 607 sample population. When the respondents were asked for their working preferences, they were found engaged in agriculture with 73.61 percent of the total workforce (Tab. 1). This was followed by religious practice as an occupation of "gomchens", lay priests who perform Buddhist rituals in monasteries, and at the household level. There are 39 gomchens (10.29\% of the total workforce) in the village. They receive food grain and milk products for their services. There are $3(0.79 \%)$ Lamas in the village and 3 (0.79\&) are working in Buddhist monasteries in Dehradun, India. Government jobs are still alien to the Lauriaps. So far, only 9 people $(2.37 \%)$ have entered into government jobs. About 18 persons (4.75\%) from the sample households are in the Royal Bhutan Army, followed by 7 drivers (1.85\%) and 4 policemen (1.05\%), who serve as the Royal Bhutan Police. As such, the service sector comprises 10.02 percent of the total workforce, which is close to the percentage figure of religious workers. The fourth important livelihood base is weaving of woollen cloth and 7 women $(1.85 \%)$ were found engaged in this sector as their primary occupation. They sometime work in Thimphu for the business class if required, so that their weaving skill is widely acclaimed in Bhutan. There are 4 carpenters $(1.85 \%)$ in the village, ranking in the fifth position in the village workforce. They prepare wooden boxes, almirah, small altars, and furniture items. and wooden masks used to perform dances in the Buddhist temples, and these are sold in Thimphu for good prices. Blacksmithing is a very rare occupation in Bhutan and two blacksmiths $(2.57 \%)$ work in the village and manufacture sickles, axes, knives and spades. Likewise, there is one mason who takes up house construction jobs. Thus, carpentry, masonry and blacksmithing engage 7 persons altogether( $1.85 \%$ ) similar to those engaged in weaving. Recently, one person has started up a timber business with a grinding machine and power 
chains. One cook and a waiter have also joined the staff of the hotel in Thimphu, showing their connection to the outer world.

Tab. 1 Livelihood Status of Sample Households in the Village of Lauri, 2009

Tab. 1. Izvori prihoda uzorka kućanstava sela Lauri, 2009.

\begin{tabular}{|c|c|c|}
\hline Sl. No. & Occupations & Working Population \\
\hline 1. & Agriculture & $279(73.61)$ \\
\hline 2. & Government Jobs & $09(2.37)$ \\
\hline 3. & Royal Bhutan Army & $4(1.05)$ \\
\hline 4. & Royal Bhutan Police & $7(1.85)$ \\
\hline 5. & Drivers & $7(1.85)$ \\
\hline 6. & Weaving & $39(10.29)$ \\
\hline 7. & Gomchens (Lay priests) & $3(0.79)$ \\
\hline 8. & Monks & $3(0.79)$ \\
\hline 9. & Lamas & $2(1.85)$ \\
\hline 10. & Carpenters & $1(0.53)$ \\
\hline 11. & Blacksmiths & $1(0.26)$ \\
\hline 12. & Masons & $1(0.26)$ \\
\hline 13. & Timber Business & $1(0.26)$ \\
\hline 14. & Cook & $379(100)$ \\
\hline 15. & Waiter &
\end{tabular}

Source: Field work, 2009. Figures in parenthesis are percentage of the total workforce.

Izvor: samostalno istraživanje, 2009. Brojevi u zagradama označuju postotak ukupne radne snage.

\section{LABOUR MIGRATION AS A MAJOR LIVELIHOOD STRATEGY IN THE VILLAGE OF LAURI}

Winter labour migration is a less studied subject in Bhutan, which has not received due attention from both Bhutanese and international academics. There are no local records and routine data sources to account for the volume and flow of local Bhutanese labourers, moving from one region to another within Bhutan and also to adjoining Indian neighborhoods in search of cash income to compensate their daily requirements. However, winter labour migration is an increasingly important aspect of Bhutanese rural livelihoods. Such migration has to be seen as integral to coping with the environmental forces, survival and the essentially subsistence way of living in Bhutan. The aim of this paper is to set labour migration in Bhutan into a broader context to see how these migratory paths are developed, based on the more factual details collected from this case study.

The outstanding feature of all highlander societies of the mountain world is the transhumance, which is seasonally controlled movement of pastoral communities from their summer settlements to the winter habitat of warmer valleys in search of pastures for their animals. This practice is found among the Brokpas, Layaps and other yak herders of Bhutan (Chand, 2000 and 2004). However, the winter migration of Lauriaps is not transhumance in that sense. The winter migration is another form of population movement 
of many primitive societies, which takes place due to the rigidity of climate as well as to socio-economic compulsions. This is a traditional mode of survival of those indigenous groups, who earn a significant portion of their livelihood during their winter migration period for the rest of the year. Indeed, they also move with their cattle to their winter pastures, but family members engage themselves in economic pursuits other than cattle herding. The majority work as labourers on the farms, and on roads and other construction sites.

Tab. 2 Winter Migration Pattern in the Village of Lauri, 2009

Tab. 2. Zimske migracije u selu Lauri, 2009.

\begin{tabular}{|c|c|c|c|c|}
\hline \multirow{2}{*}{ Sl. No. } & \multirow{2}{*}{$\begin{array}{l}\text { Migration } \\
\text { Categories }\end{array}$} & \multicolumn{3}{|c|}{ Population } \\
\hline & & Male & Female & Total \\
\hline 1. & Labour Migration & 99 & 104 & 203 (66.56) \\
\hline 2. & Cattle Rearing & 45 & 16 & $61(20)$ \\
\hline 3. & Carpentry & 13 & - & $13(4.26)$ \\
\hline 4. & Lay priests & 11 & - & $11(3.60)$ \\
\hline 5. & Business & 5 & 1 & $\begin{array}{ll}6 & (1.96) \\
\end{array}$ \\
\hline 6. & Weaving & - & 5 & $5 \quad(1.63)$ \\
\hline 7. & Masonry & 2 & - & $\begin{array}{ll}2 & (0.65) \\
\end{array}$ \\
\hline 8. & Blacksmiths & 1 & - & $\begin{array}{ll}1 & (0.32) \\
\end{array}$ \\
\hline 9. & Not Specified & 3 & - & $3 \quad(0.98)$ \\
\hline & Total & 179 & 126 & $305(100)$ \\
\hline
\end{tabular}

Source: Field work, 2009. Figures in parenthesis are the percentage of total migrants.

Izvor: terensko istraživanje provedeno 2009. Brojevi u zagradama označuju postotak svih migranata.

The village of Lauri is an area of marginal agriculture. They practice one-crop-a-year agriculture. The agriculture does not provide enough food round the year and people move out from the village to work as labourers to earn wages. The winter migration pattern of Lauri village is presented in Tab. 2. It is evident that out of a total of the 379 working sample population of the village, 80.47 percent of them move out during the winter to work in the warmer valleys. Of the total of 305 winter migrants, the majority of them are labour migrants $(66.55 \%)$. About one fifth (20\%) of winter migrants come with their cattle to winter pastures, usually one person from each household. The winter pastures of the village of Lauri are located at 17 different locations, where grasses are available during the winter months. This is a traditional arrangement that connects highland people with the warmer valleys. One very significant trading bond also exists between the people of Lauri and the Brokpas, who migrate to the Lauri area from the Merak Sakteng region during winter. The Brokpas come to Lauri village to barter their milk products during winter. They keep all their milk products with their "Nepos" (family friends) in Lauri, who barter these milk products with food grain. They also get some butter or cheese in return. As the cold winter sets in in the upper reaches, the Lauriaps slowly move towards the winter pastures, which they occupy through December to February. A maximum of 17 families have their pastures at Daptshathang, followed by 11 families in Takaphung and 10 families in Patpanadang. The fourth important pasture land is Khowrong, which is occupied by 5 families. The remaining 13 pasture areas are occupied by two to three households in a group. These pastures are spread over a distance of two to five days walk from Lauri. 
The herders live in thatched huts with at least one member from each family, while the others earn wages as labourers working in the town and villages. Carpenters rank in third place with 4.26 percent of the total winter migrants, followed by gomchens (lay priests [3.60\%]), who perform poojas and religious rituals in the villages. The business class (1.96\%) also forms a sizeable proportion, engaged in the sale of local products moving from village to village. Some skilled weavers (1.64\%) from Lauri go to the towns of Thimphu and Gelphu during winter. There are two masons $(0.65 \%)$ and one blacksmith $(0.32 \%)$. There are three other migrants $(0.98 \%)$ who have not specified the work they do. One important result of the labour migration is the higher number of females (51.23\%) outnumbering the males, while in the total winter migration the males $(58.68 \%)$ dominate the females.

\section{SIZE CHARACTERISTICS AND COMPOSITION OF THE LABOUR MIGRANTS}

Labour migration demands detailed treatment because of its higher economic relevance in the village economy of Lauri. The low level of education and lack of other opportunities are formidable barriers so, therefore, the Lauriaps continue to work as labourers. Table 3 gives size characteristics and composition of the labour migrants. One important characteristic of the labour migrants is that they are not trained workers accustomed to or specialized in one particular job. They undertake several jobs as per availability during their stay in the work place. As such, a single worker is found engaged in many jobs and the figure shown in the above table does not tally with the actual number of labour migrants.

Construction activity engages the majority (24\%) of the labour migrants due to a variety of developmental programmes, such as construction of roads, bridges, schools, hospitals and other infrastructural work being undertaken by Royal Government of Bhutan. The demand for labour is always very high.

Tab. 3 Size Characteristics and Composition of Labour Migrants of Village Lauri, 2009

Tab. 3. Karakteristike i sastav migrirajuće radne snage sela Lauri, 2009.

\begin{tabular}{|c|c|c|}
\hline Sl.No. & Nature of Jobs & No. of Workers \\
\hline 1. & Construction work & $189(24.00)$ \\
\hline 2. & Logging/Timber Cutting & $157(19.92)$ \\
\hline 3. & Transportation of Oranges & $140(17.77)$ \\
\hline 4. & Farm work & $140(17.77)$ \\
\hline 5. & Porters & $79(10.10)$ \\
\hline 6. & Bamboo Collection & $67(8.50)$ \\
\hline 7. & Bush Cutting & $15(1.90)$ \\
\hline 8. & Apple Collection & 1 \\
\hline
\end{tabular}

Source: Field work, 2009. Figures in parenthesis are percentage of the total workforce. Workers are engaged in more than one job as per the job availability from place to place and time to time.

Izvor: terensko istraživanje provedeno 2009. Brojevi u zagradama označuju postotak ukupne radne snage. Radnici mogu obavljati više poslova istovremeno, ovisno o radnome mjestu i vremenu.

The next important job is timber cutting or logging, which engages 19.92 percent of the labour force. Lauriaps are known for their skills in timber cutting. Bhutan earns 
high revenue from its forest resources. Orange production in southern Bhutan has also gained momentum in recent years and they are exported in large quantities to neighbouring Bangladesh. This sector absorbs a sizeable proportion (17.77\%) of labourers to transport oranges from the remote village to the roadside. The same number of people from the village of Lauri $(17.77 \%)$ is found working in the agricultural fields in nearby villages during the winter months. In recent years, the World Food Programme has been implemented in Bhutan. About 10.02 percent of labourers from the village of Lauri are hired as porters, which provides them with a good income. Some people are also involved in bamboo collection (8.50\%) and bush cutting (1.90\%) in and around the villages. One labourer has been recorded as working in the apple orchard in Paro in western Bhutan, about $700 \mathrm{~km}$ away from the village of Lauri.

\section{RURAL-RURAL AND RURAL-URBAN DIVIDE OF THE LABOUR MIGRANTS}

Far-Eastern Bhutan is a peripheral, remote, local resource-based economic region in Bhutan. The local inhabitants have lived there and earned their livelihood by the utilization of geographically scattered resources by adopting seasonal vertical movements from higher to lower altitudes and vice-versa. The practice of winter migration has therefore become part of their survival strategy, ever since they occupied these marginal highlands. However, this practice was restricted between the movements from higher altitude to lower altitude villages. The people of the village of Lauri used to barter locally produced goods with their counterparts living in warmer valleys during the winter months. In the beginning, the local population pursued Jhum or shifting cultivation and animal husbandry as a way of subsistence living. Life was hard and the people lived in poverty. Changes occurred only when Bhutan embarked upon the new era of development after the launching of Five Year Plans in the 1960s. Creation of various kinds of jobs related to labour requirements have led to long-distance movements from remote villages, breaking their traditional dependence on warmer valleys.

Tab. 4 Rural-Urban Divide of the Labour Migrants of the Village of Lauri, 2009

Tab. 4. Ruralno-urbana dihotomija migrirajuće radne snage sela Lauri, 2009.

\begin{tabular}{|c|c|c|c|c|}
\hline Sl. No. & Nature of Jobs & Rural to Rural & Rural to Urban & Total \\
\hline 1. & Construction Work & $66(34.92)$ & $123(65.08)$ & $189(100)$ \\
\hline 2. & Logging/Timber Cutting & $126(80.25)$ & $31(19.75)$ & $157(100)$ \\
\hline 3. & Transportation of oranges & $40(28.57)$ & $100(71.43)$ & $140(100)$ \\
\hline 4. & Farm Work & $101(72.14)$ & $39(27.86)$ & $140(100)$ \\
\hline 5. & Porters & $18(22.78)$ & $61(77.20)$ & $79(100)$ \\
\hline 6. & Bamboo Cutting & $67(100)$ & - & $67(100)$ \\
\hline 7. & Bush Cutting & $15(100)$ & - & $15(100)$ \\
\hline 8. & Apple collection & $1(100)$ & - & $1(100)$ \\
\hline
\end{tabular}

Source: Field work, 2009. Figures in parenthesis are percentage of the total workforce. Workers are engaged in more than one job as per the job availability from place to place and time to time.

Izvor: terensko istraživanje provedeno 2009. Brojevi u zagradama označuju postotak ukupne radne snage. Radnici mogu obavljati više poslova istovremeno, ovisno o radnome mjestu i vremenu. 
The growing demand for labour in the towns and their surroundings has attracted labourers from the countryside, since Bhutan has grown towards an urbanized economy in recent years. Consequently, seasonal migration from the village of Lauri, conceptualized as a geographical response and more so as a non-monetary factor, has become a trade-off decision between cost and return. The young adults are largely seen working in towns while the middle-aged and elderly people still work in the rural areas. These changes in migration patterns and the rural - urban divide of migrants can be attributed to the expansion of the Bhutanese economy, and labourers are now seeking better wages for better living conditions. Data presented in Tab. 4 provide the job-wise location of workers in the villages and urban areas. Besides the last three categories of jobs which are rural centric, construction workers $(65.08 \%)$ and porters $(77.22 \%)$ are mainly concentrated in urban areas. On the contrary, logging $(80.25 \%)$ and farm work $(72.14 \%)$ are jobs performed in rural surroundings, except for some workers engaged in saw- mills and on agriculture farms located in close vicinity to the small urban areas.

\section{DESTINATION AREAS AND REGIONAL DISTRIBUTION OF LABOUR MIGRANTS}

People from the village of Lauri move in search of seasonal work to different regions of Bhutan and even to some parts of India such as Arunachal Pradesh. However, their movement is confined more to southern Bhutan. Tab. 5 presents the mobility behaviour of labour migrants.

Tab. 5 Mobility Behaviour of Labour Migrants of the Village of Lauri, 2009

Tab. 5. Odredišta migranata sela Lauri, 2009.

\begin{tabular}{|c|c|}
\hline Destination areas & No. of Workers \\
\hline Southern Bhutan & $94(46.30)$ \\
\hline Eastern Bhutan & $73(35.96)$ \\
\hline Central Bhutan & $4 \quad(1.97)$ \\
\hline Western Bhutan & $17(8.37)$ \\
\hline Arunachal Pradesh, India & $15(7.38)$ \\
\hline Total Labour Migrants & $203(100)$ \\
\hline
\end{tabular}

Source: Field work, 2009.Figures in parenthesis are percentage of total labour migrants.

Izvor: terensko istraživanje provedeno 2009. Brojevi u zagradama označuju postotak svih radnika migranata.

The majority of the labour migrants (46.30\% ) work in the three southern districts of Bhutan, namely Samdrup Jongkhar, Gelphu and Samchi. They are found in a maximum number in the Samdrup Jongkhar district, particularly in the nearest town of Jomotsangkha. About 30 percent of the total workers are in the town of Jomotsangkha alone, followed by Longchenphu which receives 19.21 percent of the total labourers. As such, 50 percent of the total labourers from the village of Lauri are working in its two nearest towns. Eastern Bhutan, which is the district of Trashigang in particular, has the second highest concentration of labour migrants with 35.96 percent of the total. The remaining parts of Bhutan such as the central and western parts receive a minimal number with 1.97 percent and 8.37 percent of the total labour migrants. At present, there are 8 workers from the village 
of Lauri in Thimphu, the national capital of Bhutan, and an equal number of 8 workers are found working in Haa town, the western most part of Bhutan. There are 4 workers in Bumthang and one in Paro. A few people also search for jobs in India. The proximity of Arunachal Pradesh attracts labour migrants from the village of Lauri, who move across the border due to their traditional trade links and social connections.

\section{CONCLUSIONS}

For Bhutan, labour migration has both positive and negative aspects. The traditional mode of subsistence, based on the extraction of local resources as a social activity originating from a practice of collectivism and community living, is declining with time. The value of self-reliance and customary regulation is also declining with the increase in developmental interventions and enforced legislations. Dependence of local people on the government is increasing with an increase in the capacity of the State to provide market products. However, the statistics as gathered from this case study suggest that about two-third of the total workforce of the village people of Lauri are still engaged in agriculture This was followed by religious practice as an occupation of "gomchens", lay priests who perform Buddhist rituals in monasteries, and at household level. This reflects their strong faith in Buddhist tradition. They get food grain and milk products for their services. Lamas from this village are even working in Buddhist monasteries in Dehradun, India. Government jobs are still alien to Lauriaps, showing their minimal connections to the outside world. However, this case study has demonstrated that winter labour migration is an increasingly important aspect of Bhutanese rural livelihoods. Such migration has to be seen as integral to coping with environmental forces, survival and the essentially subsistence way of living in Bhutan. The factual details collected from the village of Lauri also prove that these migratory paths are developed, based on the mode of a seasonal practice adopted by the remote communities as a livelihood strategy for their survival. This is a traditional mode of survival among those indigenous groups who earn a significant portion of their livelihood during their winter migration period for the rest of the year. Indeed, they also move with their cattle to their winter pastures, but family members engage themselves in economic pursuits other than the cattle herding. They work largely as labourers on the farms, and on roads and other construction sites.

It is evident that around 80.47 percent of the migratory population of the village of Lauri move out during the winter to work in warmer valleys, the majority of them being labour migrants (66.55\%). One important result of the labour migration is the highest number of females (51.23\%) outnumbering the males, while in the total winter migration the males $(58,68 \%)$ dominate the females. They are not trained workers accustomed to or specialized in one particular job. They undertake several jobs as per availability during their stay in the work place. As such, a single worker is found engaged in many jobs. The young adults are seen largely working in the towns, while the middle-aged and elderly people still work in rural areas. These changes in migration patterns and the rural - urban divide of migrants can be attributed to the expansion of the Bhutanese economy, with labourers now are seeking better wages for better living conditions. 
At the village level, the concept of mutuality and reciprocity of labour is being gradually replaced by cash transactions. Over the past decade, policy and programmes have been geared towards private construction sector development, beginning with a gradual privatization process for the construction activities, followed by mechanization schemes and HRD support programmes for the private construction sector. The economy is still poorly diversified in Bhutan and some very remote areas in the north and far-east have been left desolated. Southern and western Bhutan have largely benefited from the development process. Thus the current socio-economic situation suggests that rural households in the marginal areas have to create and adapt their own strategies of survival in relation to the transition from a resource rich community to a community depending on a labour market. This case study of a marginal Bhutanese community from far-eastern Bhutan has demonstrated very clearly that labour migration is a survival strategy that local people are working out now in order to cope with the ongoing changes in the Bhutanese economy.

\section{ACKNOWLEDGEMENTS}

The author is deeply grateful to Mr. Dorji Tenzin, the BA student in Geography/Economics III semester, Sherubtse College Kanglun, Royal University of Bhutan, who collected field information for the present research in 2009. This work could not have been undertaken without the field support extended by him during my tenure as the Colombo Plan Professor from India to the Royal Government of Bhutan.

\section{REFERENCES}

Abrar,C.R., 2005: Labour migration from SAARC Countries: Reality and Dynamics, Refugee and Migratory Movement Research Unit, University of Dhaka, 35.

Brown, Barbara., B. 1983: The Impact of Male Labour Migration on Women in Botswana, African Affairs, $82(328), 367-388$.

Castles, S., 1999: International Migration and the Global Agenda: Reflections on the 1998 UN Technical Symposium, International Migration, 37(1), 5-19.

Chand, R. 2000: Brokpas in Transition -A Study of Tribal Self-Reliance in Bhutan, Sherub Doenme,5(1\&2), 47-74

Chand, R., 2004: Brokpas - The Hidden Highlanders of Bhutan, Pahar, Nainital, 164p.

Chand,R., 2009a: Population Mobility Behavior and External Linkages of a Village Community in Eastern Bhutan, Population Dynamics of Bhutan, An Occasional Publication of the Centre of Population and Development Studies, Sherubtse College, Royal University of Bhutan, Kanglung, 117-138.

Chand,R., 2009b: Monpas of Bhutan: A Study of Tribal Survival and Development Responses, Bulletin of Hiroshima University Museum,(1), 25-37.

Chhetri,P., 2012: How Bhutan's Dependence on Indian Workers Drain Rupee, Bhutan Observer,April 7,2012.

Deki, 2009: Economic Activity Rates of Bhutan 2005, Population Dynamics of Bhutan, An Occasional Publication of the Centre of Population and Development Studies, Sherubtse College, Royal University of Bhutan, Kanglung, 49-62. 
Gross National Happiness Commission, 2008: Tenth Five year plan, Vol.1, Main Document 2008-2013, Royal Government of Bhutan, Thimphu.

Khatri,Sridhar,K., 2007: Labour Migration, Employment and Poverty Alleviation in South Asia, Updated Summary of the Proceedings of the Regional Seminar, jointly organized by South Asia Centre for Policy Studies and Friedrich Elbert Stfteng, Kathmandu, Nepal, August 9-10,2007

Labour Market Information Bulletin, Issue 2, 2007: Department of Employment, Ministry of Labor and Human Resources, Royal Government of Bhutan, Thimphu.

Mosse, D.et.el., 2002: Brokered Livelihood: Debt, Labour Migration and Development in Tribal Western India, Journal of Development Studies, 38 (5),59-68.

Norbu, N.,2008: Labour Migration Trends, Policies and Challenges, http://www,adbi.org/files/2008,05.29. cpp,norbu,country presentation, Bhutan, pdf. (01.04.2012.)

Population and Housing Census of Bhutan, 2005: Office of the Census Commissioner, Royal Government of Bhutan, Thimphu, Bhutan.

Poverty Analysis Report Bhutan, 2003: National Statistical Bureau, Royal Government of Bhutan, Thimphu, Bhutan, 33p.

Taylor, E. J., 1999: The New Economics of Labour Migration and the Role of Remittances in the Migration Process, International Migration, 37(1), 63-68.

\title{
SAŽETAK
}

\section{Migracija radne snage kao strategija privređivanja u istočnom Butanu: studija slučaja marginalnoga butanskog naselja}

\author{
Raghubir Chand
}

Fenomen migracije radne snage u Butanu potaknut je regionalnim disparitetima u upotrebi resursâ u različitim ekološkim i društvenim okolnostima. Natprosječna razina siromaštva i nepovoljni klimatski čimbenici prisiljavaju ljude na migracije u područja s boljim mogućnostima privređivanja, najčešće privremeno tijekom zimskih mjeseci. Slabljenje pritiska nezaposlenosti na domaćem tržištu te priljev novčanih sredstava imaju dvije svrhe - porastom potrebe za radnom snagom na drugim tržištima posljednjih godina, rad je postao resurs lokalne ekonomije i sigurnosni ventil za probleme nezaposlenosti na domaćem tržištu. Kao prostor analize odabrano je naselje Lauri u istočnom Butanu, najveće naselje istoimenoga gewoga (butanska jedinica lokalne samouprave).

Lauri Gewog jedna je od najzabačenijih regija krajnjeg istoka Butana. Udaljena je tri dana hoda od Jomotshangkhe (bivši Diafam), pograničnoga grada u butanskom okrugu Samdrup Jogkhar. Nalazi se na tromeđi Butana na zapadu, indijske savezne države Arunachal Pradesh na istoku te indijske savezne države Assam na jugu. Taj gewog sastoji se od od trinaest naselja koja broje 697 kućanstava i 2802 stanovnika te obuhvaća površinu od $278 \mathrm{~km}^{2}$. Nadmorska je visina gewoga između 1200 i $3500 \mathrm{~m}$. 
Migracija radne snage iz istočnog Butana u Assam i Arunachal Pradesh izuzetno je važna strategija privređivanja stanovnika marginalnih pograničnih područja. S etničkog i lingvističkog stajališta istok Butana vrlo je homogeno područje u odnosu na Assam i Arunachal Pradesh. Migracija radne snage u Indiju kao posljedica siromaštva i dispariteta u ekonomskom razvoju najvažniji je aspekt ekonomije pograničnih dijelova Butana. Podaci prikupljeni iz sto kućanstava naselja Lauri tijekom siječnja 2009. temelj su ovog istraživanja i mogu poslužiti u detaljnijim analizama problematike migracije i marginalnih područja odvojenih od glavnih ekonomskih tokova. Učinci globalizacije i globalnog tržišta također su jasno vidljivi.

Received (Primljeno): 2013 -04-12

Accepted (Prihvaćeno): 2013-12-04

Raghubir Chand,

Department of Geography

Kumaun University Nainital,

Uttarakhand, India

raghuvir_chand@rediffmail.com 
